\title{
32 Using research evidence to improve practice
}

\author{
Mark Rickinson, Lucas Walsh, Mandy Salisbury, \\ Joanne Gleeson, and Connie Cirkony
}

\section{How to use this policy}

There are growing expectations internationally that schools and school systems will use research evidence to underpin and inform their improvement efforts (Australian Productivity Commission, 2016; British Educational Research Association [BERA], 2014; Cain, 2019; Nelson \& Campbell, 2019; Tripney et al., 2018). However, using research evidence in practice is neither simple nor straightforward, and it can be unclear what using research involves and how to do it well.

This using research evidence policy example aims to clarify the meaning, explain the rationale, and describe the practical implementation of research use in schools. It can be used:

- to articulate your overall approach to developing as a research-engaged school;

- to signal your current priorities, practices, and principles around using research;

- to show how research use connects with other areas of your work such as teaching, learning, and staff development; and

- to review progress towards, and identify future options for, strengthening research use within your school.

This policy example is intentionally broad and school policy creators are encouraged to delete and build upon the suggestions below to create a policy that best represents their school.

[To adapt and use this policy, delete or modify the text as indicated]

\section{[INSERT name of school] Using research evidence to improve practice}

\section{Rationale}

A research-engaged school has been characterised as one that places research "at the heart of the school, its outlook, systems and activity" 
(Handscomb \& MacBeath, 2003, p. 4). Central to this concept is the idea of teachers and leaders using research to make genuine and long-lasting improvements (Cain, 2019). This is about educational practice being informed by (not based on) research evidence and so involves educators combining their "professional expertise with the best external evidence from research to improve the quality of practice" (Sharples, 2013, p. 7).

The promotion of research use in schools reflects increased awareness internationally that "research-rich school and college environments are the hallmark of high performing education systems" (BERA, 2014, p. 6). Within Australian education, as in other countries, there have been growing calls for the development of an evidence-based approach and a research-rich teaching profession (Australian Productivity Commission, 2016; White et al., 2018).

\section{Purpose}

The purpose of this policy is to outline our approach to using research evidence to drive improvement across the school. It seeks to foster thoughtful engagement with and implementation of appropriate research evidence (Rickinson et al., 2020).

\section{Scope}

This policy applies to all school staff - teachers, middle leaders, senior leaders, support staff - particularly those with responsibilities relating to issues such as teaching and learning, staff development, research, and data. It is whole school in scope and applies to all aspects of the school as a learning organisation.

[INSERT specific roles and responsibilities of individuals or teams]

\section{Policy statement}

The use of research evidence at [INSERT name of school] is reflected in the commitments we make, the practices we follow, and the supports we provide.

By research evidence, we mean evidence generated through systematic studies undertaken by universities or research organisations and reported in books, reports, articles, research summaries, training courses, or events (Nelson, et al., 2017). By research-informed practice, we mean practice that is informed by research evidence alongside other forms of evidence such as educators' professional knowledge (Brown, 2018). By use, we mean the process of actively engaging with and drawing on research evidence to inform, change, and improve practice (Coldwell et al., 2017). By thoughtful use, we mean use that involves critical engagement with the evidence, shared deliberation about its meaning, and careful integration of aspects of the evidence within practice (Rickinson et al., 2020). 


\section{Commitments}

[INSERT name of school] is committed to using research evidence and research-informed practice to improve outcomes for all students, especially those who are socially disadvantaged (Education Endowment Foundation [EEF], 2019).

[INSERT name of school] is committed to the use of research evidence and research-informed practice being a feature of decision-making across all levels of the school (Brown \& Greany, 2018; Cain, 2019).

[INSERT name of school] is committed to developing and promoting research-informed teaching throughout all areas and levels of the school (Cain, 2019; Stoll et al., 2018).

[INSERT name of school] is committed to engaging with and implementing research evidence thoughtfully and to using research evidence that is rigorous and appropriate for our context (Cain, 2019; Rickinson et al., 2020).

[INSERT name of school] is committed to supporting and developing not only staff skillsets to understand research but also staff mindsets to be open to its meaning (Earl \& Timperley, 2009; Rickinson et al., 2020).

[INSERT name of school] is committed to supporting and enabling staff to work collaboratively to make sense of research and determine how to use it in context (Earl, 2015; Stoll et al., 2018).

[INSERT name of school] is committed to supporting and developing research use through its leadership and vision, culture and ethos, and structures and resources (Cain, 2019; Stoll et al., 2018).

\section{Practices}

At [INSERT name of school], we take seriously the need to identify research evidence that is rigorous and appropriate for our context and to engage with and implement that evidence thoughtfully (Cain, 2019; Rickinson et al., 2020).

At [INSERT name of school], we use research evidence and researchinformed practice to better understand our students and our community and how we can meet their needs (Cain, 2019; Penuel et al., 2016).

At [INSERT name of school], we draw on and use research evidence and research-informed practice as part of planning, delivering, and evaluating our teaching, learning, and assessment (Cain, 2019; Stoll et al., 2018).

At [INSERT name of school], we consider research evidence and researchinformed practice when we are planning new initiatives, scaling up pilot initiatives, and assessing existing initiatives (Cain, 2019; Penuel et al., 2016).

At [INSERT name of school], we seek out research evidence and researchinformed practice when we are faced with a significant new challenge or a significant new opportunity (Cain, 2019; Penuel et al., 2016).

At [INSERT name of school], we engage with and discuss research evidence and research-informed practice within our senior leadership team and school council/governing body (EEF, 2019; Stoll et al., 2018). 
At [INSERT name of school], we engage with and discuss research evidence and research-informed practice within our staff teams and professional learning communities (Cain, 2019; Stoll et al., 2018).

At [INSERT name of school], we consider research evidence and researchinformed practice when we are designing and providing professional learning opportunities within the school (Penuel et al., 2016; Stoll et al., 2018).

At [INSERT name of school], we discuss and develop research evidence and research-informed practice in collaboration with external research organisations and networks and other schools (Cain, 2019; Stoll et al., 2018).

At [INSERT name of school], we draw on and refer to relevant research evidence in our communications and interactions with parents and the wider community (EEF, 2019; Stoll et al., 2018).

\section{Supports}

Senior leaders at [INSERT name of school] promote and model the use of research evidence through the strategic vision of the school and their own actions formally and informally (Cain, 2019; Stoll et al., 2018).

The leadership team at [INSERT name of school] ensures that there are dedicated resources (time, funding, space, etc.) to support research engagement within and across the school (Cain, 2019; Stoll et al., 2018).

Middle leaders at [INSERT name of school] support other staff in being able to access, evaluate, understand, and use research evidence and researchinformed practice (Cain, 2019; Stoll et al., 2018).

The staff of [INSERT name of school] includes a designated research champion to coordinate efforts and support engagement with and use of research across the school (Cain, 2019; Stoll et al., 2018).

Staff at [INSERT name of school] are supported to be able to access research evidence through provisions such as database access, publication subscription, newsletter summaries, and invited speakers (Cain, 2019; Stoll et al., 2018).

Staff at [INSERT name of school] are encouraged to develop as researchinformed practitioners through professional learning, performance development, postgraduate study, and recruitment, induction, and promotion (Cain, 2019; Stoll et al., 2018).

The leadership team at [INSERT name of school] supports connections and partnerships with external research organisations, brokers and networks, and other research-engaged schools (Cain, 2019; Stoll et al., 2018). 


\section{Rating of evidence base}

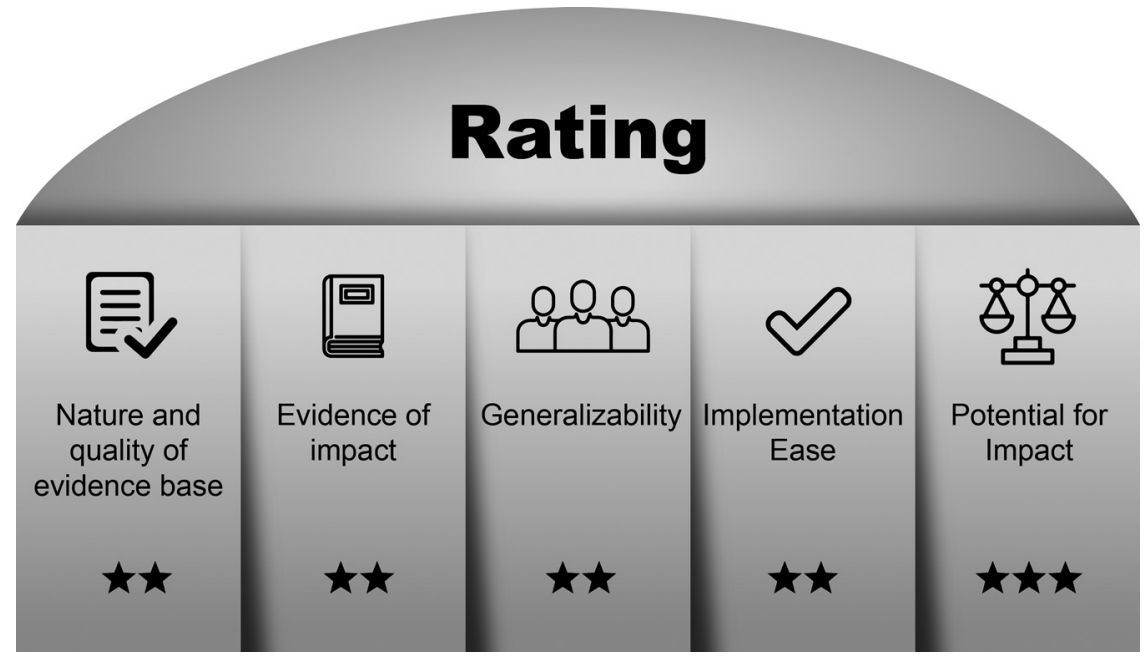

Figure 32.1. Using Research Evidence to Improve Practice Rating of Evidence.

Author Note. The evidence base on the use of research evidence in education is still developing. Empirical understandings are well developed for some topics but still emerging for others. There have been numerous studies on whether and how teachers and leaders access and use research and what enables and impedes them to do so. Studies of the impact of research use, however, have been fewer in number. The evidence base on the impact of research use on classroom practice and student learning outcomes is not well developed. As others have described: there is "limited but growing evidence" (Cain, 2019 , p. 6) and "little evaluation of the impact" (Tripney et al., 2018, p. 9). Work that has been done, though, suggests benefits in terms of teacher skills and confidence (Bell et al., 2010), school and system performance (Mincu, 2015), and student attainment (Rose et al., 2017). The developing nature of the evidence base on research use in schools means that the evidence for generalisability is moderate. While studies of the nature and extent of research use and enablers and barriers have been undertaken with samples including different kinds of schools and educators, the efficacy of evidence use interventions across different school contexts is not yet well established. Increasing and improving the use of research evidence in schools takes commitment, time, and support. Research use is not a quick add on but rather needs to be integral to the culture and the core work of the school. It is about professional learning, not information transfer. Its implementation, therefore, needs to be taken seriously.

\section{Authorship}

Associate Professor Mark Rickinson, Faculty of Education, Monash University Professor Lucas Walsh, Faculty of Education, Monash University

Mrs Mandy Salisbury, Faculty of Education, Monash University

Dr Joanne Gleeson, Faculty of Education, Monash University

Dr Connie Cirkony, Faculty of Education, Monash University

[INSERT RELEVANT STAFF MEMBERS] 


\section{Related policy and documents}

\section{[INSERT RELEVANT POLICY AND DOCUMENTS]}

Australian Government Productivity Commission. (2016). National education evidence base. Productivity commission inquiry report.https://www.pc.gov.au/ inquiries/completed/education-evidence/report/education-evidence.pdf

British Educational Research Association. (2014). Research and the teaching profession: Building the capacity for a self-improving education system. Final Report of the BERA-RSA Inquiry into the Role of Research in Teacher Education.https://www.thersa.org/globalassets/pdfs/bera-rsa-research-teaching-profes sion-full-report-for-web-2.pdf

White, S., Nuttall, J., Down, B., Shore, S., Woods, A., Mills, M., \& Bussey, K. (2018). Strengthening a research-rich teaching profession for Australia. https:// www.aare.edu.au/assets/documents/Strengthening-a-research-rich-teachingpro fession-FOR-RESEARCH-PAGE-v2.pdf

\section{Date of ratification}

This policy was ratified on the [INSERT DATE].

\section{Date of review}

This policy will be reviewed by [INSERT DATE].

\section{Further reading}

Creaby, C., Dann R., Morris A., Theobald K., Walker M., \& White, B. (2017). Leading research engagement in education: Guidance for organisational change.http://www.cebenetwork.org/sites/cebenetwork.org/files/CEBE $\% 20-\% 20$ Leading $\% 20$ Research $\% 20$ Engagement $\% 20$ in $\% 20$ Education $\% 20-\%$ 20Apr\%202017.pdf

Godfrey, D., \& Brown, C. (Eds.). (2019). An ecosystem for research-engaged schools. London: Routledge.

Sharples, J., Albers, B., Fraser, S., \& Kime, S. (2019). Putting evidence to work: A school's guide to implementation. https://educationendowmentfoundation.org. uk/tools/guidance-reports/a-schools-guide-to-implementation/

Stoll, L., Greany, T., Coldwell, M., Higgins, S., Brown, C., Maxwell, B., Stiell, B., Willis, B., \& Burns, H. (2018). Evidence-informed teaching: Selfassessment tool for teachers. London: Chartered College of Teaching.

\section{Expert consultation}

Studies of research-engaged schools have shown that promoting the use of research within the school can be helped by developing meaningful links with researchers, research organisations, research brokers and research networks 
beyond the school (e.g., Stoll et al., 2018; Tripney et al., 2018). Exploring opportunities for input from, and partnerships with, universities, professional associations, research brokers (e.g., Evidence for Learning) and professional learning providers may well be helpful for the development and implementation of a school-level policy on research use.

\section{References}

Australian Government Productivity Commission [AGPC]. (2016). National education evidence base: Productivity commission inquiry report. https://www.pc.gov.au/inquiries/ completed/education-evidence/report/education-evidence.pdf

British Educational Research Association [BERA]. (2014). Research and the teaching profession: Building the capacity for a self-improving education system. Final report of the BERA-RSA inquiry into the role of research in teacher education. https://www. thersa.org/globalassets/pdfs/bera-rsa-research-teaching-profession-full-report-for-web2.pdf

Bell, M., Cordingley, P., Isham, C., \& Davis, R. (2010). Report of professional practitioner use of research review: Practitioner engagement in andlor with research. Coventry: CUREE, GTCE, LSIS \& NTRP.

Brown, C. (2018). Achieving evidence-informed policy and practice in education: EvidenceED. Bingley: Emerald.

Brown, C., \& Greany, T. (2018). The evidence-informed school system in England: Where should school leaders be focusing their efforts? Leadership and Policy in Schools, 17(1), 115-137.

Cain, T. (2019). Becoming a research-informed school: Why? What? How?London: Routledge.

Coldwell, M., Greaney, T., Higgins, S., Brown, C., Maxwell, B., Stiell, B., Stoll, L., Willis, B., \& Burns, H. (2017). Evidence-informed teaching: An evaluation of progress in England. https://assets.publishing.service.gov.uk/government/uploads/system/uploads/ attachment_data/file/625007/Evidence-informed_teaching_-_an_evaluation_of_pro gress_in_England.pdf

Earl, L. M. (2015). Reflections on the challenges of leading research and evidence use in schools. In C. D. Brown (Ed.), Leading the use of research and evidence in schools (pp. 146-152). London: Institute of Education Press.

Earl, L. M., \& Timperley, H. (2009). Understanding how evidence and learning conversations work. In L. M. Earl \& H. Timperley (Eds.), Professional learning conversations (pp. 1-12). Dordrecht: Springer.

Education Endowment Foundation [EEF]. (2019). The EEF guide to becoming an evidence-informed school governor and trustee. https://educationendowment foundation.org.uk/public/files/Publications/EEF_Guide_for_School_Governors_and_ Trustees_2019.pdf

Handscomb, G., \& MacBeath, J. E. (2003). The research-engaged school. Essex: Essex County Council, FLARE.

Nelson, J., Mehta, P., Sharples, J., \& Davey, C. (2017). Measuring teachers' research engagement: Findings from a pilot study. London: Education Endowment Foundation. https://educationendowmentfoundation.org.uk/public/files/Evaluation/Research_ Use/NFER_Research_Use_pilot_report_-_March_2017_for_publication.pdf 


\section{Rickinson et al.}

Nelson, J., \& Campbell, C. (2019). Using evidence in education. In A. Boaz, H. Davies, A. Fraser \& S. Nutley (Eds.), What works now? Evidence-informed policy and practice revisited (pp. 131-149). Bristol: Policy Press.

Mincu, M. E. (2015). Teacher quality and school improvement: what is the role of research? Oxford Review of Education, 41(2), 253-269.

Penuel, W. R., Briggs, D. C., Davidson, K. L., Herlihy, C., Sherer, D., Hill, H. C., Farrell, C. C., \& Allen, A. (2016). Findings from a national survey of research use among school and district leaders (Technical Report No. 1). http://ncrpp.org/assets/ documents/NCRPP_Technical-Report-1_National-Survey-of-Research-Use.pdf

Rickinson, M., Walsh, L., Cirkony, C., Salisbury, M., \& Gleeson, J. (2020). Quality use of research evidence framework. https://www.monash.edu/education/research/ projects/qproject/publications/quality-use-of-research-evidence-framework-qurereport

Rose, J., Thomas, S., Zhang, L., Edwards, A., Augero, A., \& Rooney, P. (2017). Research learning communities: Evaluation report and executive summary. London: Education Endowment Foundation.

Sharples, J. (2013). Evidence for the Frontline. A report for the Alliance of Useful Evidence. https://www.alliance4usefulevidence.org/assets/EVIDENCE-FOR-THEFRONTLINE-FINAL-5-June-2013.pdf

Stoll, L., Greany, T., Coldwell, M., Higgins, S., Brown, C., Maxwell, B., Stiell, B., Willis, B., \& Burns, H. (2018). Evidence-informed teaching: Self-assessment tool for schools. London: Chartered College of Teaching.

Tripney, J., Gough, D., Sharples, J., Lester, S., \& Bristow, D. (2018). Promoting teacher engagement with research evidence. https://www.wcpp.org.uk/wp-content/uploads/ 2018/11/WCPP-Promoting-Teacher-Engagement-with-Research-Evidence-October2018.pdf

White, S., Nuttall, J., Down, B., Shore, S., Woods, A., Mills, M., \& Bussey, K. (2018). Strengthening a research-rich teaching profession for Australia. https:// www.aare.edu.au/assets/documents/Strengthening-a-research-rich-teaching-professionFOR-RESEARCH-PAGE-v2.pdf 